\title{
ABILITY OF POLYVALENT (CROTALIDAE) \\ ANTIVENIN TO NEUTRALIZE \\ MYONECROSIS, HEMORRHAGE \\ AND LETHALITY INDUCED \\ BY TIMBER RATTLESNAKE \\ (CROTALUS HORRIDUS \\ HORRIDUS) VENOM
}

\author{
By \\ MICHAEL SCOTT SMITH \\ Bachelor of Science \\ Guilford College \\ Greensboro, North Carolina \\ 1979

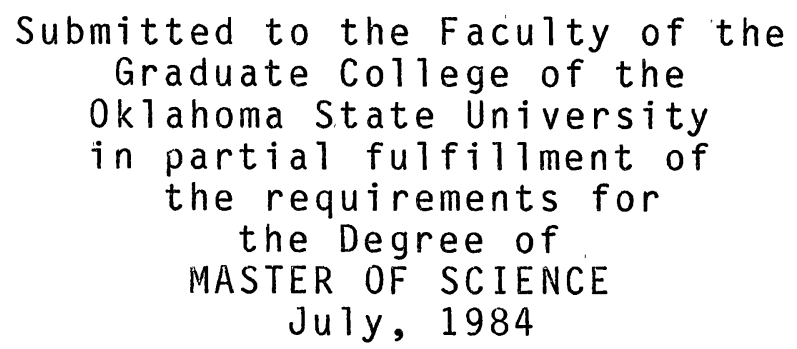


$\therefore \quad: \quad, \quad$

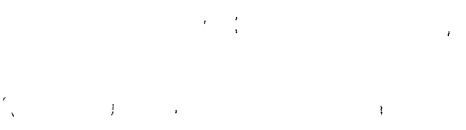

Thesis

$$
\begin{aligned}
& 1984 \\
& 3655 a \\
& \text { cop.2 }
\end{aligned}
$$


ABILITY OF POLYVALENT (CROTALIDAE)

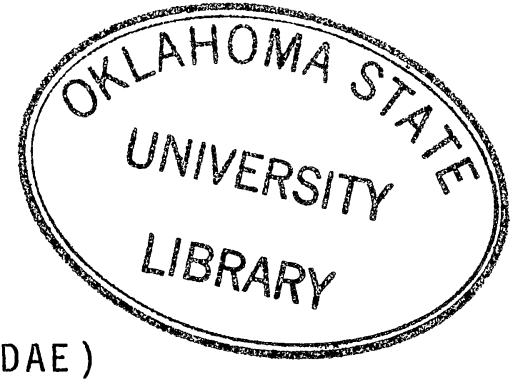

ANTIVENIN TO NEUTRALIZE

MYONECROSIS, HEMORRHAGE

AND LETHALITY INDUCED

BY TIMBER RATTLESNAKE

(CROTALUS HORRIDUS

HORRIDUS) VENOM

Thesis Approved:

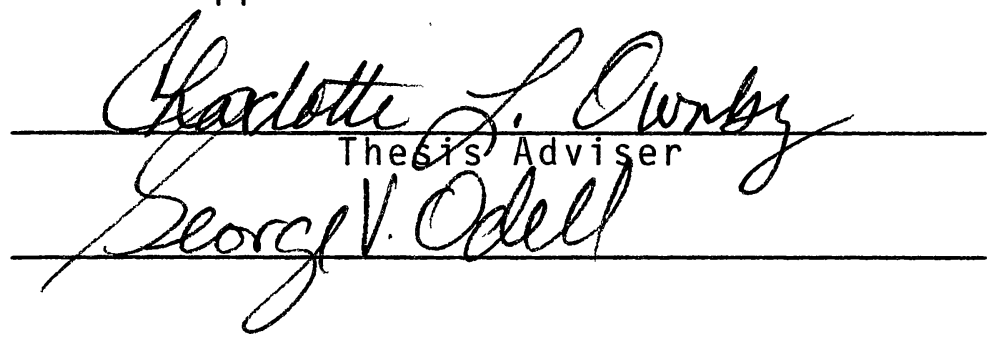

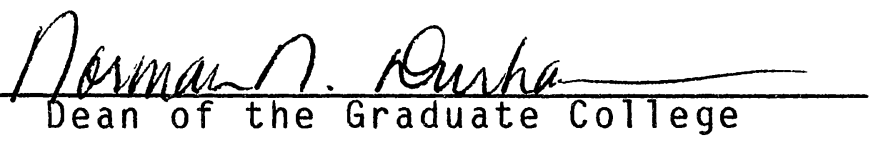




\section{PREFACE}

The lethal and local effects of crotalus horridus horridus (timber rattlesnake) venom were measured. Local effects include myonecrosis and hemorrhage. The ability of polyvalent (Crotalidae) antivenin to neutralize these effects was also measured.

I wish to express my sincere gratitude to Dr. Charlotte Ownby without whom this work would have been impossible. Her support was without measure. I would like to thank Dr. George Odell and Dr. Lester Rolf for their contributions to this research project and for acting as members of my committee. I would like to thank Dr. E. C. Short for his support throughout this program. Special thanks are extended to $\mathrm{Dr}$. Jose Gutierrez and Terry Colberg for their technical assistance and friendship. Additional thanks are due the members of the Department of Physiological Sciences at 0klahoma State University and especially to the following persons: Vinita Pill, Debbie Czarniecki, Dr. Bruce Lessley, Mary Bober, Terry Jessen, Ruth Kagen, Fred Alavi and Michael Hermes.

I would especially like to extend my sincerest appreciation to Ruth Anderson, Debbie Smith and my brothers Chip and Jeff for their encouragement and support and most importantly my mother, simply for understanding. 


\section{TABLE OF CONTENTS}

Chapter

Page

I. INTRODUCTION . . . . . . . . . . . 1

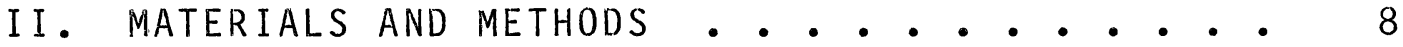

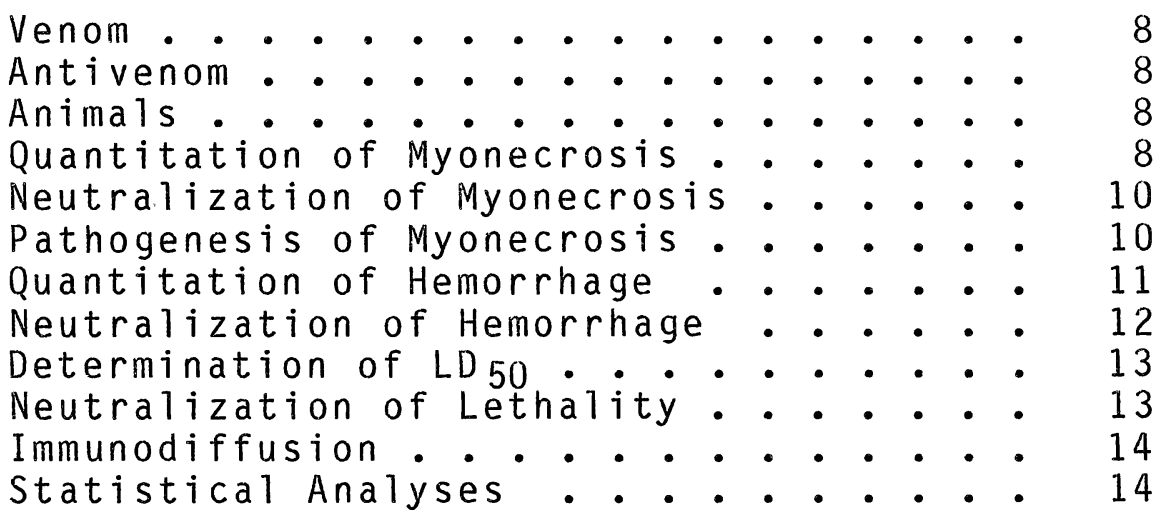

III . RESULTS . . . . . . . . . . . . . 16

Pathogenesis of Myonecrosis • • • • • 16 Neutralization of Myonecrosis . . . . 23 Neutralization of Hemorrhage . • • • • 30 LD 50 Determination and Neuralization of Lethality. . . . . . . . . . 30 Immunodiffusion . . . . . . . . . 33 Summary •. • • . • • • • • • • • 33

IV. DISCUSSION . . . . . . . . . . 37

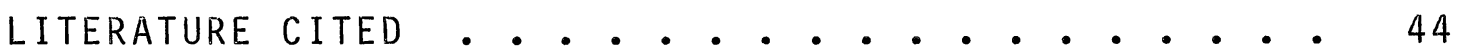


TABLE

Table Page

I. Ability of polyvalent (Crotalidae) antivenin to neutralize crotalus horridus horridus 


\section{LIST OF FIGURES}

Figure

Page

1. Light micrograph of a representative section of mouse skeletal muscle 24 hours after injection of a 4.0 micrograms/gram dose (i.m.) of crude Crotalus horridus horridus venom illustrating vacuolation ..............

2. Light micrograph of a repesentative section of mouse skeletal muscle 24 hours after injection of a 4.0 micrograms/gram dose (i.m.) of crude Crotalus horridus horridus venom illustrating necrosis ...............

3. Comparison of myonecrosis and vacuolation induced by crude crotalus horridus horridus venom in female white mice at a 4.0 micrograms/gram i.m. dose

4. Light micrograph of a representative section of mouse skeletal muscle 72 hours after injection of a 4.0 micrograms/gram dose (i.m.) of crude Crotalus horridus horridus venom ......

5. Light micrograph of a representative section of mouse skeletal muscle one week after injection of a 4.0 micrograms/gram dose (i.m.) of crude crotalus horridus horridus venom . . . . .

6. Effect of polyvalent antivenom on myonecrosis induced by crude Crotalus horridus horridus venom injected $i . m$. in female white mice as measured by myonecrosis index ........

7. Effect of polyvalent antivenom on vacuolation induced by crude crotalus horridus horridus venom injected $i . m$. in female white mice as measured by vacuolation index ........

8. Effect of polyvalent antivenom on myonecrosis induced by crude crotalus horridus horridus venom injected i.m. in female white mice as measured by myonecrosis index excluding vacuolated cells ............ 
Figure

9. Effect of polyvalent antivenom on the amount of hemorrhage induced by crude crotalus horridus horridus venom injected i.m. in female white mice as measured by mean corrected hemoglobin method . . . . . . . . . . . . . .

10. Immunodiffusion plates containing polyvalent antivenom and crude crotalus horridus horridus venom ..$\cdot \cdot \cdot \cdot \cdot \cdot \cdot \cdot \cdot \cdot \cdot \cdot \cdot \cdot \cdot \cdot$. 


\section{LIST OF SYMBOLS}

$\begin{array}{ll}\text { cm } & \text { centimeter } \\ \text { i.m. } & \text { gram } \\ \text { i.p. } & \text { intramuscular } \\ \text { i.v. } & \text { intraperitoneal } \\ \text { LD 50 } & \text { intravascular } \\ \mathrm{M} & \text { lethal dose 50\% } \\ \mathrm{mg} & \text { molar concentration } \\ \mathrm{ml} & \text { milligram } \\ \mathrm{mm} & \text { milliliter } \\ \mathrm{NaCl} & \text { millimeter } \\ \mathrm{nm} & \text { sodium chloride } \\ \text { Os0 } & \text { nanometer } \\ \mathrm{S} . \mathrm{C} . & \text { osmium tetroxide } \\ \mathrm{S.E} . & \text { subcutaneous } \\ \end{array}$




\section{CHAPTER I}

\section{INTRODUCTION}

Snakebite poisoning is a serious medical problem in the United States and especially world wide. Swaroop and Grab (1956) have estimated that between 30,000 and 40,000 deaths occur each year throughout the world. Russell et a1. (1975) has reported that approximately 45,000 bites occur each year in the United States with nearly 8,000 bites by poisonous snakes. In a comprehensive study in 1959, Parrish (1980) recorded 6,680 poisonous snakebites in the United States (excluding Alaska and Hawaii) resulting in 15 deaths. The relatively few number of deaths in the United States is most likely due to the extensive use of antivenom coupled with proximity to hospital facilities. Antivenom, however, may not prevent the local effects induced by snake venom. Such effects include hemorrhage, myonecrosis and edema (Ohsaka, 1979; Ownby et a1., 1982), often resulting in the loss or dysfunction of the damaged extremity. Therefore, although lethality is the primary concern, the major health problem in the United States today resulting from snake venom poisoning is the local tissue destruction. 
Various treatments have been tried in efforts to reduce the effects of snake bites. One such method is the 1igature-cryotherapy method (Stahnke et al., 1957 ; Stahnke and McBride, 1966). This method involves placing a ligature above the injection site and then the placement of the $1 \mathrm{imb}$ into a cold environment. Stahnke proposes that since most enzymes present in the venom are active at temperatures between 37 and 45 degrees centigrade, the cryotherapy technique would reduce or prevent the action of these enzymes. However, many snake venoms contain toxic components such as myotoxin a (Cameron and Tu, 1977) that are not enzymes but still cause serious local damage (Ownby et al., 1976). Another treatment is the pressureimmobilization technique, whereby the bitten $1 \mathrm{imb}$ is wrapped tightly with an elastic bandage and immobilized with a splint (Sutherland and Coulter, 1981; Glenn and Straight, 1984). Sutherland and Coulter (1981), using radioimmune assays, showed delayed movement of venom in monkeys with this technique. One problem with this procedure, however, would be the potential of concentrating within a small area those toxins or components of the venom responsible for the local effects.

Another method employed is incision-suction, where an incision is made at the site of injection and direct suction is applied. The effectiveness of this treatment requires administration very soon if not immediately after poisoning (McCollough and Gennaro, 1970; Russell et al., 
1973; Efrati, 1979). McCollough and Gennaro (1970) reported that $50 \%$ of the injected venom was recovered if suction was applied within three minutes of a subcutaneous injection. A similar method is debridement of the wound and fasciotomy (Efrati, 1979). This technique involves the surgical removal of the tissue at the site of injection, based on the idea that most of the venom remains in the local area. Huang et a1. (1974), treating 54 patients, claimed that by mechanically removing the tissue containing the injected venom, most of the venom can conceivably be eliminated, thereby reducing the magnitude of the systemic intoxication and the local éffects. With severe snake venom poisoning, circulatory shock is common and fluid should be administered. Schaeffer et al. (1978) reported that fluid infusion with albumin increased survival in rats after an injection of an LDgg dose of venom.

By far the most common treatment for snake venom poisoning is serotherapy utilizing antivenoms specific for snake venoms or polyvalent antivenoms such as used in the present study. The use of antisera is based on the antibody affinity for specific toxic components in the venom. Often, corticosteroids such as cortisone and antihistamines are included with antivenom treatment to help in the management of systemic effects such as shock, anaphylaxis and serum sickness (Schottler, 1954; Allam et a1., 1956; McCollough and Gennaro, 1970; Schaeffer et al., $1979)$. 
The most widely used antivenom in the United States and that used in the present study is polyvalent (Crotalidae) antivenin, subsequently called polyvalent antivenom, available from Wyeth's Laboratories, Marietta, Pennsylvania. Polyvalent antivenom is serum from horses inoculated with a mixture of venoms from four species of snakes: Bothrops atrox, Crotalus atrox, Crotalus adamanteus and crotalus durrissus terrificus. These venoms were chosen because of the paraspecific protection against other venoms offered by the antivenom due to common antigens in venoms (Criley, 1956; Minton, 1976).

There have been several studies to determine lethality neutralization by polyvalent antivenom. Minton (1954) showed no significant neutralization of lethality induced by $\underline{C}$. atrox or $\underline{C}$. adamanteus venoms whether antivenom was administered fifteen minutes before or fifteen minutes after venom injection in mice despite the fact that these venoms are used in the antivenom production. Perhaps because of the variation in the toxicity of venoms even within the same species (Minton, 1954), the results are quite variable. Some LD 50 values and the amounts of venom neutralized by antivenom for $\underline{c}$. $\underline{h}$. horridus and $\underline{c}$. $\underline{v}$. viridis venoms are as follows: Criley (1956) reported a 2.78 micrograms/gram LD 50 (i.v., mice) for $\underline{\text {. }}$. $\underline{\text {. horridus }}$ venom; $0.1 \mathrm{ml}$ antivenom neutralized three times the LD 50 in mice. Minton (1954) reported a 9.15 micrograms/gram LD 50 (i.p., mice) for $\underline{c}$. $\underline{h}$. horridus venom; $0.1 \mathrm{ml}$ antivenom 
allowed survival of five of fourteen mice given two times the LD 50 dose if administered fifteen minutes after venom injection. Criley (1956) reported a 1.06 micrograms/gram LD50 (i.v., mice) for $\underline{C}$. $\underline{v}$. viridis venom; $0.05 \mathrm{ml}$ antivenom neutralized 2.21 times the LD50 dose. Ownby et a1. (1983) reported a 3.0 micrograms/gram LD 50 (i.m., mice) for $\underline{C}$. $\underline{v}$ viridis venom; $0.05 \mathrm{ml}$ antivenom neutralized six times the LD 50 dose.

The ability of polyvalent antivenom to neutralize lethality in the clinical situation is related to the amount of time between venom deposition and antivenom administration. Russell et al. (1973) showed with $\underline{C} \cdot \underline{v}$. helleri venom that administration of antivenom sixty minutes after venom injection resulted in no increase in survival time. With antivenom given ten minutes, twenty minutes and thirty minutes after injection, increases of $60 \%, 50 \%$ and $33 \%$, respectively, in survival rate were recorded. An $80 \%$ survival rate was recorded when antivenom was injected at the time of poisoning. Minton (1954) recorded the survival of three out of six animals when antivenom was injected (i.p.) fifteen minutes before injection of $\underline{c}$. h. horridus venom but survival of only five of fourteen animals when antivenom was injected fifteen minutes after venom injection.

Polyvalent antivenom has been shown to be effective in neutralizing hemorrhage induced by rattlesnake venoms. Ownby et al. (1984a) showed that antivenom neutralized 
hemorrhagic activity of a $24.0 \mathrm{micrograms} / \mathrm{gram}$ dose of $\underline{\mathrm{C}}$. v. viridis venom and that of a $12.0 \mathrm{micrograms} / g \mathrm{ram}$ dose of C. atrox venom. The inability of antivenom to neutralize myotoxic activity of $\underline{c}$. $\underline{v}$. viridis venom (0wnby et al., 1983 ) has generated efforts to produce an antiserum capable of neutralizing the myonecrotic effects of such venoms. Ownby et a1. (1979) produced an antiserum in rabbits against myotoxin a isolated from $\underline{\text { c. }} \underline{v}$. viridis venom. It has been shown in vitro to neutralize myonecrosis caused by crude $\underline{c}$. $\underline{v}$ viridis venom $(15 \mathrm{micrograms}$ venom per $0.09 \mathrm{~m} 1$ antiserum). This is to be compared with 3.8 micrograms venom neutralized by $0.09 \mathrm{ml}$ of polyvalent antivenom (Ownby et al., 1983). Additionally, antimyotoxin serum is able to neutralize in vivo a 0.75 micrograms/gram dose of crude $\underline{c}$. v. viridis venom, even if injected thirty minutes after venom injection (Ownby et al., 1983). Clinically, the difficulty in the treatment of snakebite cases involves many factors including the health of the individual, the time between envenomation and treatment, and most importantly, the quantity and toxicity of the venom. Snake venoms are very complex solutions containing hemorrhagic toxins, myotoxins and neurotoxins (Cameron and Tu, 1977; Sullivan et al., 1979; Sullivan and Geren, 1979). Venoms also contain many enzymes such as phospholipases, L-amino acid oxidases, nucleotidases, phosphodiesterases, cholinesterases, hyaluronidases and esterases (Iwanaga and Suzuki, 1979). Additionally, venoms cause alterations in 
the normal hemostatic mechanisms due to activities of coagulant and anticoagulant substances (Iwanaga and Suzuki, 1979), often leading to circulatory shock (Schaeffer et a1., 1979). The purpose of the present study was to measure the local and lethal effects induced by $\underline{c}$. $\underline{h}$. horridus venom and to determine the ability of polyvalent (Crotalidae) antivenin to neutralize these effects. 


\section{CHAPTER I I}

\section{MATERIALS AND METHODS}

Venom

Crude, lyophilized $\underline{C}$. $\underline{h}$. horridus venom was purchased from Ross Allen Laboratories (lot \#9363). This same lot was used in all experiments.

\section{Antivenom}

Wyeth's lyophilized polyvalent (Crotalidae) antivenin (lot \#17601, Wyeth Inc., Marietta, Pennsylvania) was reconstituted with $10.0 \mathrm{ml}$ bacteriostatic water and kept frozen before use. The same lot was used in all experiments.

\section{Animals}

Female white mice $(C D-1)$ were purchased from Charles River. The following weight classes were used: myonecrosis 18-24 grams; hemorrhage 23-26 grams; 1ethality 25-31 grams. Injection volumes were adjusted to $0.1 \mathrm{ml}$ per 20 grams body weight.

\section{Quantitation of Myonecrosis}

Two indices were used to quantitate myonecrosis 
induced by $\underline{c}$. $\underline{h}$. horridus venom. The vacuolation index is defined as the number of vacuolated cells divided by the total number of cells counted per mouse. It is a measure of the myotoxin a activity of the venom (Ownby et al., 1976). The myonecrosis index, which includes vacuolated cells, is defined as the number of necrotic cells divided by the total number of cells counted per mouse. It is a measure of the total myotoxic activity of the venom. At least $1,000-2,000$ cells were counted per mouse.

The injection site was the dorsolateral aspect of the right thigh. Animals were killed by cervical dislocation and the medial aspect (opposite of the injection site) was removed so as to avoid the tissue damage by the needle and fixed in $2 \%$ glutaraldehyde in $0.27 \mathrm{M}$ cacodylate buffer for two hours. Each muscle section was washed three times with cacodylate buffered wash (with sucrose), fixed for one hour in $1 \% \mathrm{OsO}_{4}$ in distilled water, and embedded in plastic using Poly/Bed 812 resin purchased from Polysciences, Inc. (Warrington, Pennsylvania). The tissue was oriented in the block to provide cross-sections of muscle. Five blocks from each mouse were sectioned using an LKB ultramicrotome at a thickness of 1.0 micrometers, stained with Mallory's trichrome and counted (visible at 100x) using a Zeiss light microscope equipped with a Zeiss MOP 3 Image Analyzer. 
Neutralization of Myonecrosis

Crude lyophilized $\underline{c}$. $\underline{\text { h }}$ horridus venom was dissolved in $0.85 \% \mathrm{NaCl}$ (physiologic saline, PSS) so as to give five stock solutions with concentrations ranging from $1.2 \mathrm{mg} / \mathrm{ml}$ to $0.075 \mathrm{mg} / \mathrm{ml}$. A volume of $0.1 \mathrm{ml}$ of these solutions was mixed with $1.0 \mathrm{ml}$ of either $0.85 \% \mathrm{NaCl}$ or polyvalent antivenom, allowed to mix for one hour at four degrees centigrade, centrifuged in a Brinkmann 3200 microfuge and the supernatant stored at zero degrees centigrade until needed. The injection volumes, $0.1 \mathrm{ml}$ per 20 gram mouse, contained doses ranging from 6.0 to $0.38 \mathrm{micrograms} / \mathrm{gram}$. Control animals received injections of $0.85 \% \mathrm{NaCl}$ or polyvalent antivenom alone.

The experimental design included six repetitions with each mouse receiving one dose. The mice were killed 24 hours after injection and the tissue processed as described above under Quantitation of Myonecrosis. The mean \pm standard error (S.E.) was determined for each dose and treatment.

\section{Pathogenesis of Myonecrosis}

This experiment was performed to determine the most suitable time to take tissue for the neutralization studies and to observe the time of maximum vacuolation as compared to that of myonecrosis. Crude $\underline{c}$. $\underline{h}$. horridus venom was dissolved in $0.85 \% \mathrm{NaCl}$ at a concentration of $0.8 \mathrm{mg} / \mathrm{ml}$. This corresponds to a 4.0 micrograms/gram dose based on an 
injection solution of $0.1 \mathrm{ml} / 20 \mathrm{gram}$ mouse. The mice were injected i.m. in the dorsolateral aspect of the right thigh. Muscle tissue was removed from the medial aspect of the thigh opposite the injection site at the following times post-injection: 15 and 30 minutes, $1,3,6,12,24$, 48, 72 and 96 nours, 1,2 and 4 weeks. The muscle tissue was processed for cross-sections as described above under Quantitation of Myonecrosis. Each experiment was repeated four times. Between 1,000 and 2,000 cells were counted for each mouse. Vacuolation and myonecrosis indices were used and the results are reported as mean $\pm S . E$.

Quantitation of Hemorrhage

A new method developed by 0wnby et al. (1984a) for quantitating the amount of hemoglobin in the muscle at the injection site was used as the measure of hemorrhage induced by $\underline{c}$. $\underline{h}$. horridus venom. Mice were injected (i.m.) in the dorsolateral aspect of the right thigh. One and one-half hours after injection, the mice were killed by cervical dislocation. A section of the medial aspect of the thigh was removed, placed in $3.0 \mathrm{ml}$ distilled water and homogenized for 30 seconds using a Brinkmann Polytron PT 1035 (Brinkman Instruments, Westbury, New York) at a setting of five. The homogenate was centrifuged in a clinical centrifuge for five minutes at room temperature at maximum speed $(3,000$ RPM). The supernatant was centrifuged in a Sorval1 RC2B centrifuge for 30 minutes at 18,500 RPM, 
four degrees centigrade. Hemoglobin was measured using the cyanmethemoglobin method according to Sigma technical bulletin 525 except that double strength Drabkin's solution (one vial per $500 \mathrm{ml}$ distilled water) was used. The supernatant $(1,800$ microliters) was removed so as to prevent mixing with the overlying lipid layer. It was added to $5.0 \mathrm{ml}$ of double strength Drabkin's solution, mixed and left sitting for at least 15 minutes to allow color development. The lyophilized methemoglobin standard (stock no. 525-18) supplied with the kit purchased from Sigma Chemicar Company (St. Louis, Missouri) was also mixed with double strength Drabkin's solution. Absorbance at $540 \mathrm{~nm}$ was read using a Beckmann DU-8 spectrophotometer. The grams per $100 \mathrm{ml}$ of hemoglobin were read from a standard curve. A standard curve was produced for each experiment and the same standard solutions were used for each standard curve. All results are expressed as corrected gram \% hemoglobin, determined by dividing the gram \% hemoglobin by the weight of the muscle.

Neutralization of Hemorrhage

Crude $\underline{\mathrm{C}}$. $\underline{h}$. horridus venom was dissolved in $0.85 \% \mathrm{NaCl}$ so as to give nine concentrations ranging from $9.6 \mathrm{mg} / \mathrm{ml}$ to $0.038 \mathrm{mg} / \mathrm{ml}$. A volume of $0.1 \mathrm{ml}$ of these stock solutions was added to $1.0 \mathrm{ml}$ of either $0.85 \% \mathrm{NaCl}$ or polyvalent antivenom, allowed to mix for one hour at four degrees centigrade, centrifuged in a Brinkmann 3200 microfuge for 
two minutes, and the supernatant stored at zero degrees centigrade until needed. The injection volumes, based on $0.1 \mathrm{ml} / 20$ gram mouse, contained nine halving doses from 48.0 to $0.19 \mathrm{micrograms} / g r a m$. Control animals received injections of $0.85 \% \mathrm{NaCl}$ or polyvalent antivenom alone.

Each experiment was repeated eight times. The mice were killed by cervical dislocation one and one-half hours after injection and the amount of hemorrhage determined. Results are reported as the mean $\pm S . E$.

\section{Determination of LD 50}

Ten doses, based on a $0.1 \mathrm{ml} / 20$ gram mouse injection, were prepared ranging from eleven to two micrograms/gram. Five mice per group received i.m. injections in the dorsolateral aspect of the right thigh. Twenty-four hours after injection, the number of dead mice for each dose was recorded. LD 50 values were determined using the method of Litchfield and Wilcoxin (1949). The experiment was done twice.

\section{Neutralization of Lethality}

Crude lyophilized c. h. horridus venom was dissolved in $0.85 \% \mathrm{NaCl}$ so as to give two stock solutions at concentrations of 2.5 times and 5.0 times LD 50 values ( 5.25 $\mathrm{mg} / \mathrm{m} 1$ and $10.5 \mathrm{mg} / \mathrm{ml}$ respectively). Volumes of $0.5 \mathrm{ml}$ of the stock venom solutions were mixed with $0.5 \mathrm{ml}$ of either $0.85 \% \mathrm{NaCl}$ or polyvalent antivenom, allowed to mix one hour 
at four degrees centigrade, centrifuged for two minutes in a Brinkmann 3200 microfuge, and the supernatant removed and stored at zero degrees centigrade until needed. Each group of five mice received injections, based on $0.1 \mathrm{ml}$ per 20 gram mouse, in the dorsolateral aspect of the right thigh. Twenty-four hours after injection, the number of dead mice divided by the number of mice used was recorded. If all mice in the antivenom group survived while all in the control group died, neutralization was considered complete.

\section{Immunodiffusion}

Agarose was dissolved in distilled water to give a $1 \%$ solution. A small amount of sodium azide was added to prevent bacterial growth. Eight plates were prepared using $6.0 \mathrm{ml}$ per dish. Each dish measured $5.3 \mathrm{~cm}$ in diameter. The agar was cut using a template giving one center well and six outer wells. The distance between wells measured $9.0 \mathrm{~mm}$. Each well was filled twice with approximately 20 microliters of solution at 10 minute intervals. Varying concentrations of crude $\underline{c}$. $\underline{h}$. horridus venom were tested against varying concentrations of polyvalent antivenom and anti-myotoxin a serum (prepared from rabbits, Ownby et al., 1979). The plates were allowed to develop for 20 hours at room temperature before being photographed.

\section{Statistical Analyses}

Analysis of variance was performed to determine 
variation within the experiments for neutralization of myonecrosis and neutralization of hemorrhage. Tukey's honestly significant difference test (Wilcox et al., 1979) was performed to determine significant difference between a pair of means. Results were determined as significant at $p<0.05$. 
CHAPTER I I I

RESULTS

Pathogenesis of Myonecrosis

Injection of crude $\underline{\text {. }} \underline{\text { h }}$ horridus venom $i . m$. in mice causes, among other effects, vacuolation and necrosis of muscle cells. Figure 1 shows a light micrograph of a representative tissue section with cells in the vacuolated state. Figure 2 shows cells in the necrotic state. These states can be quantitated using light microscopy to obtain vacuolation and myonecrosis indices. Figure 3 illustrates the change in vacuolation and myonecrosis indices over time at venom doses of $4.0 \mathrm{micrograms} / \mathrm{gram}$. The number of muscle cells in the vacuolated state peaks near 12 hours after injection and does not significantly change after this time. Visual inspection shows an apparent decrease in the number of vacuolated cells at later times after injection. Myonecrosis, however, increases with time until 48 hours after injection. Beyond 48 hours, it became difficult to count individual cells. At 72 hours (Figure 4), many of the muscle cells were amorphous masses. Macrophages were often seen inside and around damaged muscle cells. At one week after injection (Figure 5), small cells with centrally placed and often double nuclei 
Figure 1. Light micrograph of a representative section of mouse skeletal muscle 24 hours after

injection of a $4.0 \mathrm{micrograms} / \mathrm{gram}$ dose

( $i$.m.) of crude Crotalus horridus horridus venom illustrating vacuolation.

$V$, vacuolated muscle cells

$M$, normal muscle cells (X 136)

Figure 2. Light micrograph of a representative section of mouse skeletal muscle 24 hours after

injection of a $4.0 \mathrm{micrograms} / \mathrm{gram}$ dose

( $i . m$.$) of crude crotalus horridus horridus$ venom illustrating necrosis. Note $\frac{\text { necrotic }}{\text { nections }}$ (N) muscle cells. A cell with hypercontracted myofilaments $(N)$ is located on the left half of the figure. (X 256) 

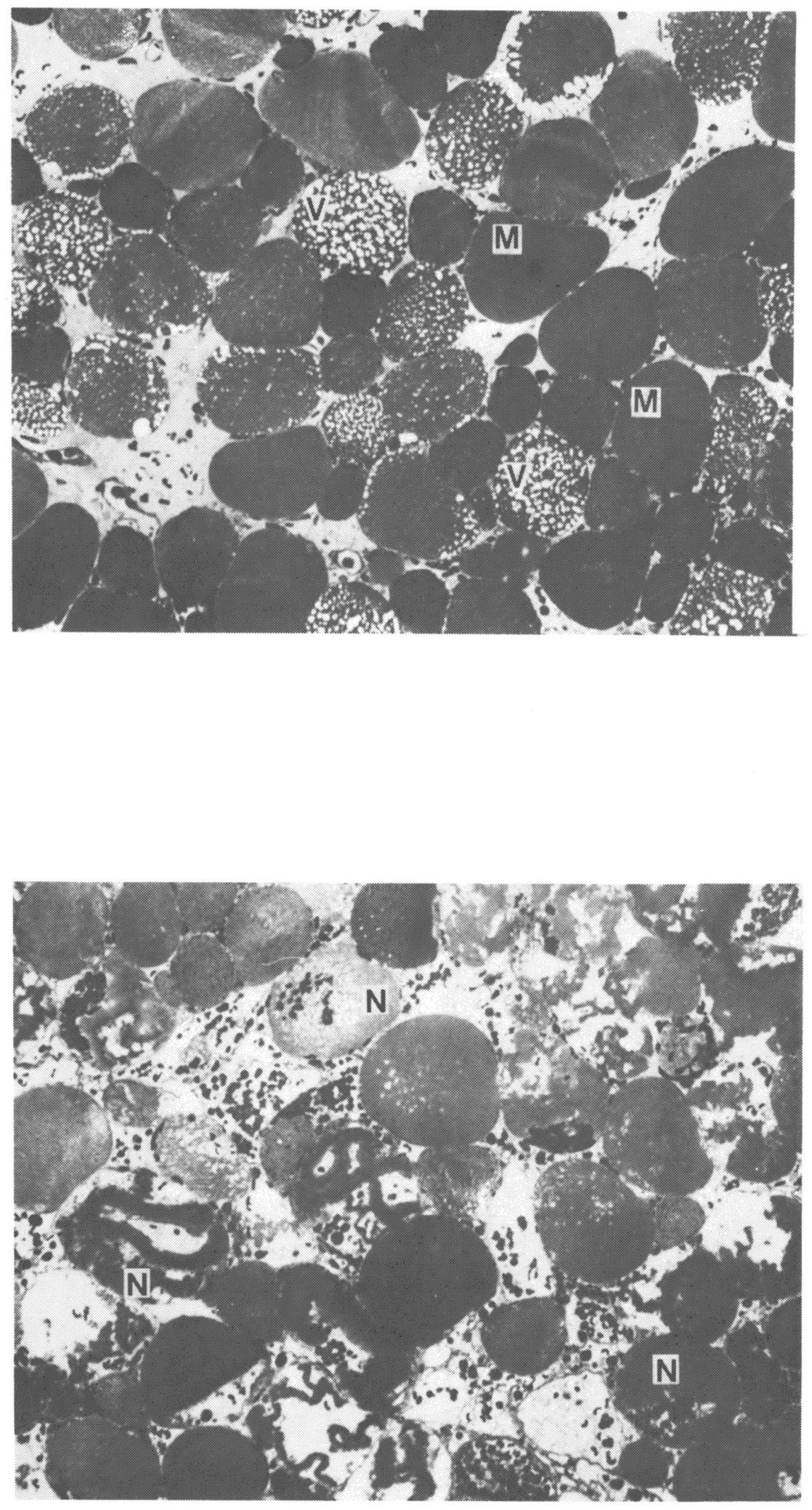
Figure 3. Comparison of myonecrosis and vacuolation induced by crude crotalus horridus horridus venom in female white mice at a $4.0 \mathrm{micrograms} / \mathrm{gram}$ dose (i.m.). ( necrotic cells; o vacuolated cells) Values are mean \pm S.E. $\quad(n=4)$ 


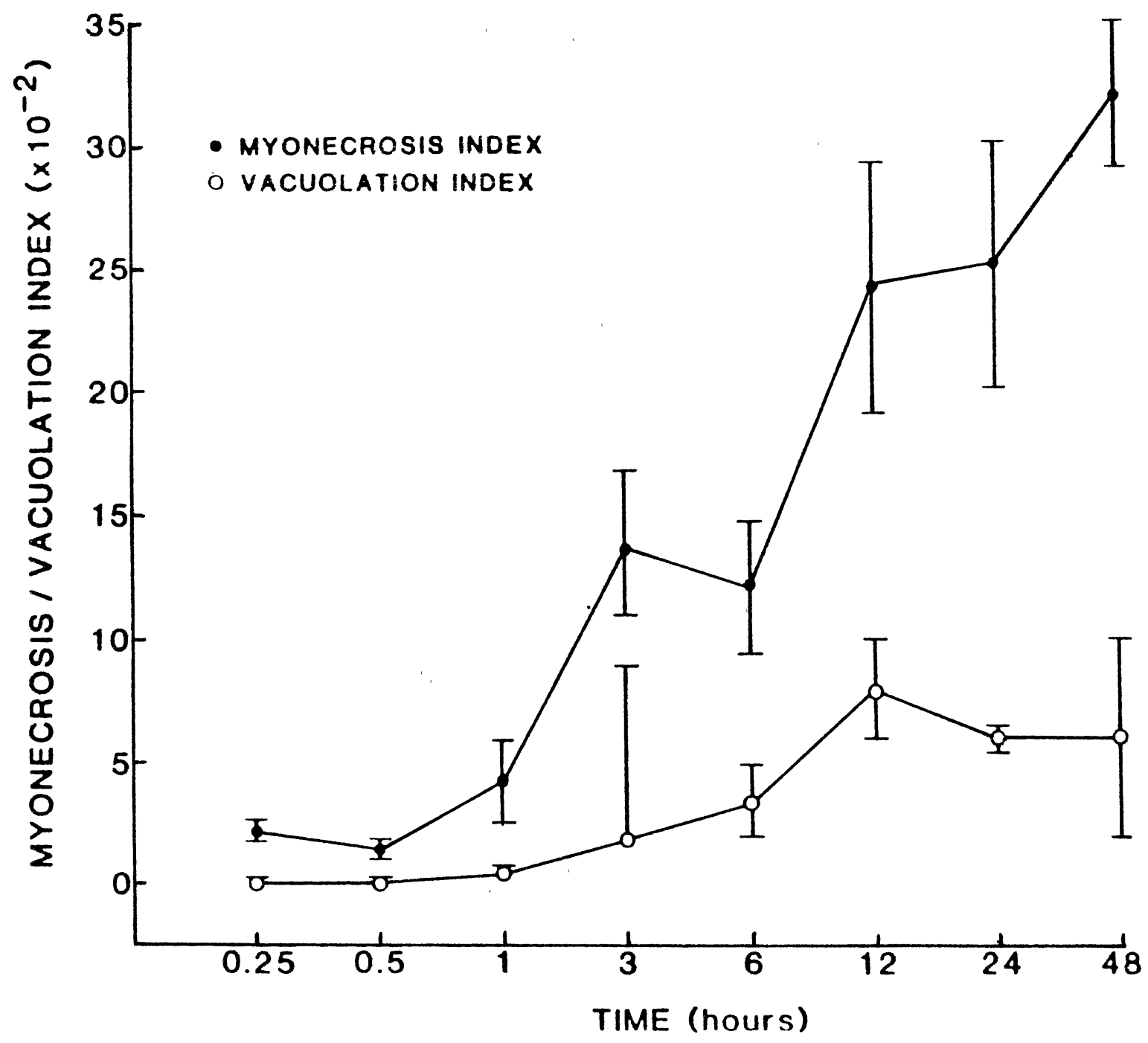


Figure 4. Light micrograph of a representative section of mouse skeletal muscle 72 hours after injection of a $4.0 \mathrm{micrograms} / \mathrm{gram}$ dose ( $i$. m.) ) of crude crotalus horridus horridus venom. Note amorphous necrotic muscle cells within the arrows. ( $x$ 328)

Figure 5. Light micrograph of a representative section of mouse skeletal muscle one week after injection of a $4.0 \mathrm{micrograms} / \mathrm{gram}$ dose (i.m.) of crude crotalus horridus horridus venom. Note regenerating muscle cells (R) with centrally placed nuclei (arrow heads). $(x \quad 275)$ 

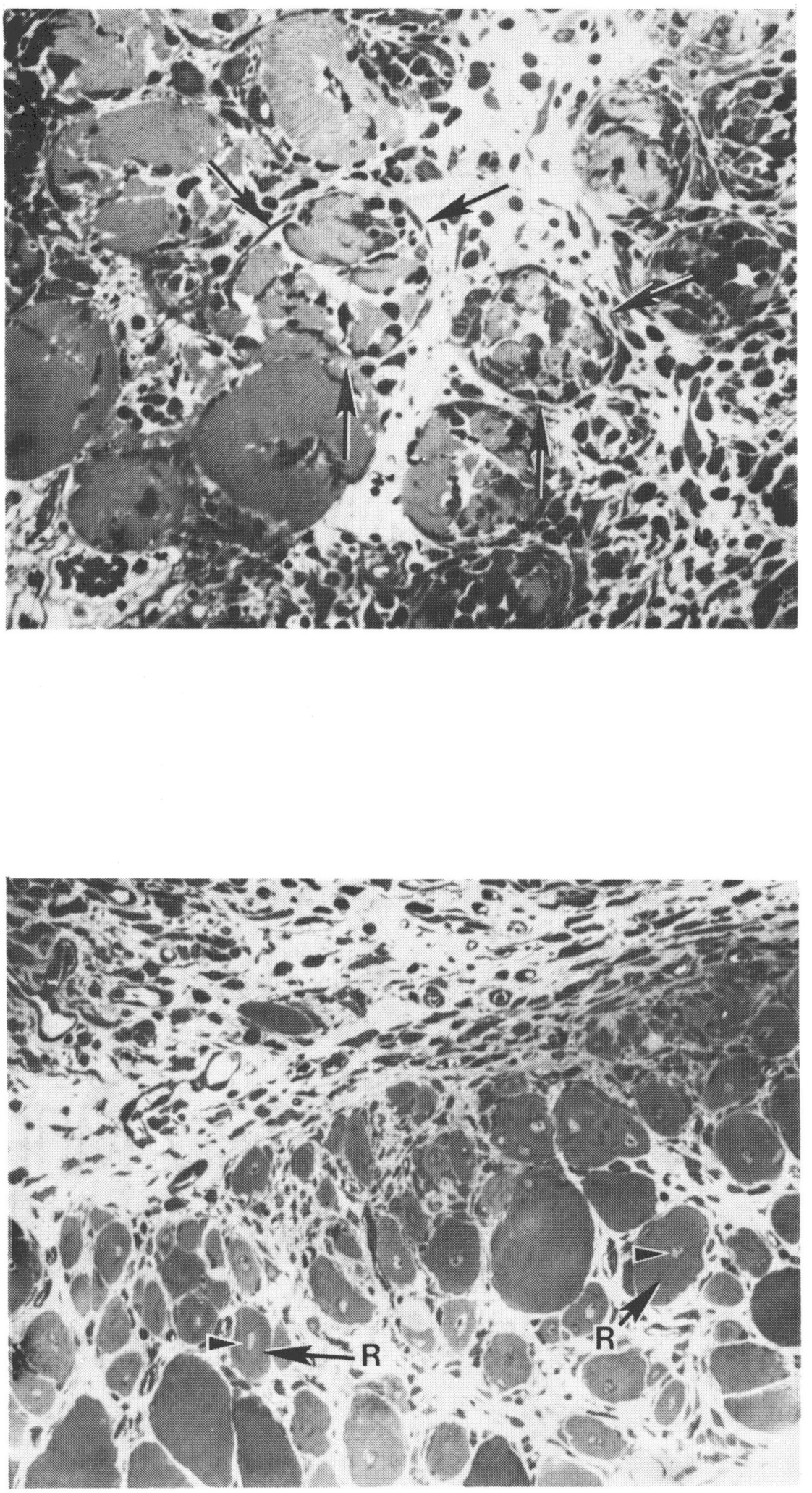
were obvious. At doses of $1.5 \mathrm{micrograms} / \mathrm{gram}$ or higher, many macrophages were located intracellularly with large numbers of fibroblasts and diffuse connective tissue located in the extracellular spaces. At higher doses, the myofilaments of some cells were hypercontracted, forming dark bands across the cell (Figure 2). Many erythrocytes were observed in the extracellular spaces due to hemorrhage induced by the venom.

Neutralization of Myonecrosis

Figure 6 illustrates that polyvalent antivenom significantly neutralized $(p<0.05)$ myonecrosis at venom doses of 3.0 and $6.0 \mathrm{micrograms} / \mathrm{gram}$. Although the statistical analysis did not show it to be significantly different at $p<0: 05$, the data indicated that the myonecrosis induced by venom plus $0.85 \% \mathrm{NaCl}$ to be less than that induced by venom plus polyvalent antivenom at doses of 0.38 and $0.75 \mathrm{micrograms} / \mathrm{gram}$.

Figure 7 shows the ability of polyvalent antivenom to neutralize vacuolation of muscle cells. There was a significant difference only at $0.75 \mathrm{micrograms} / g \mathrm{ram}$ $(p<0.05)$. As with the myonecrosis index, vacuolation induced by venom plus $0.85 \% \mathrm{NaCl}$ was less than that induced by venom plus polyvalent antivenom.

Figure 8 shows the number of necrotic cells at each dose level excluding the vacuolated cells. This graph illustrates the ability of polyvalent antivenom to 
Figure 6. Effect of polyvalent antivenom on myonecrosis induced by crude crotalus horridus horridus venom injected i.m. in female white mice as measured by myonecrosis index.

(o C. h. horridus venom + antivenom)

(• $\bar{c} \cdot \underline{h}$. horridus venom + PSS)

Values are meant S.E. $\quad(n=6)$

* indicates significant at $p<0.05$ 


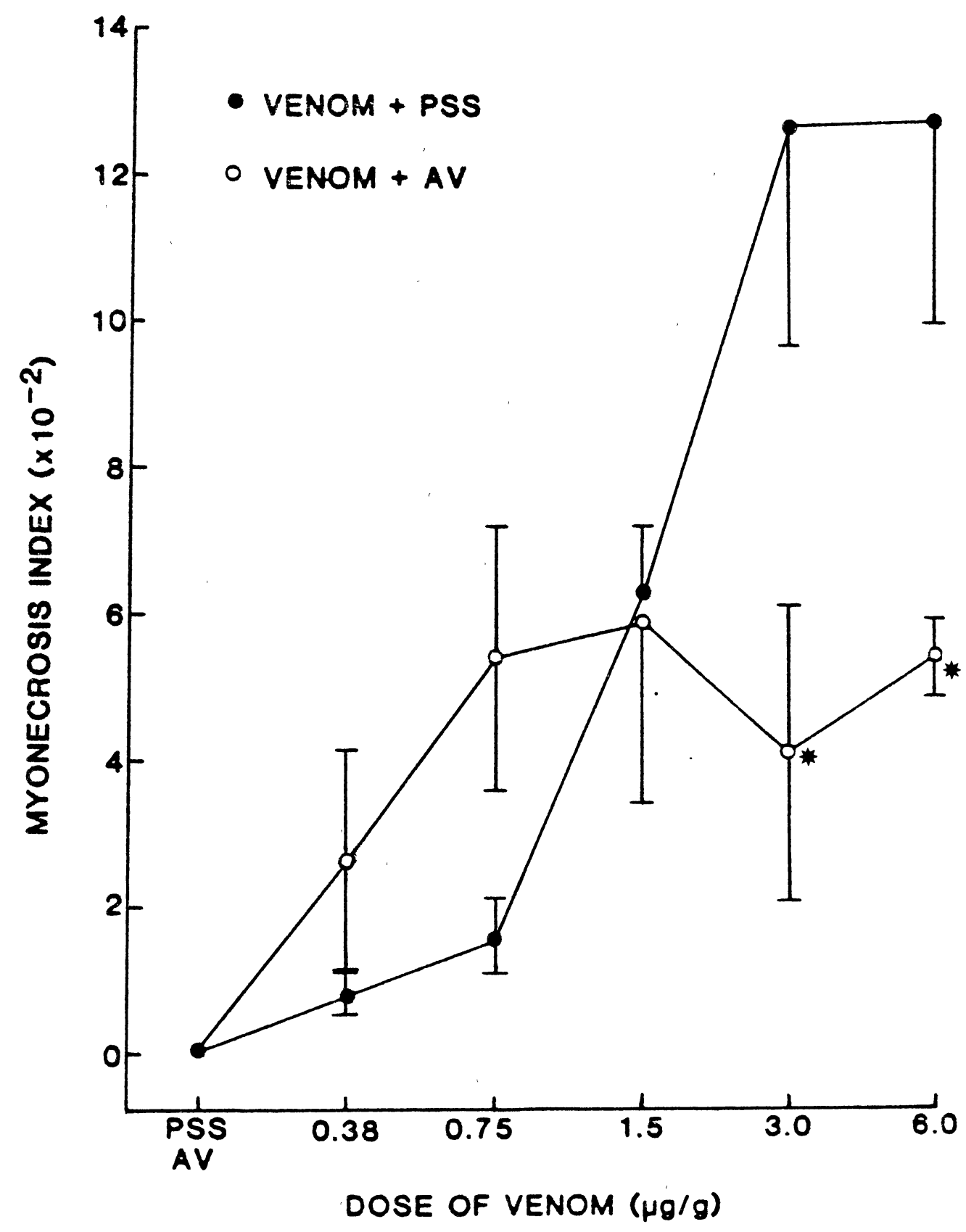


Figure 7. Effect of polyvalent antivenom on myonecrosis induced by crude crotalus horridus horridus venom injected i.m. in female white mice as measured by vacuolation index.

(o c. h. horridus venom + antivenom)

(- $\bar{c} \cdot \bar{h} \cdot \overline{h o r r i d u S}$ venom + PSS)

Values are mean $\mathrm{S}$.E. $\quad(n=6)$

* indicates signifficant at $p<0.05$ 


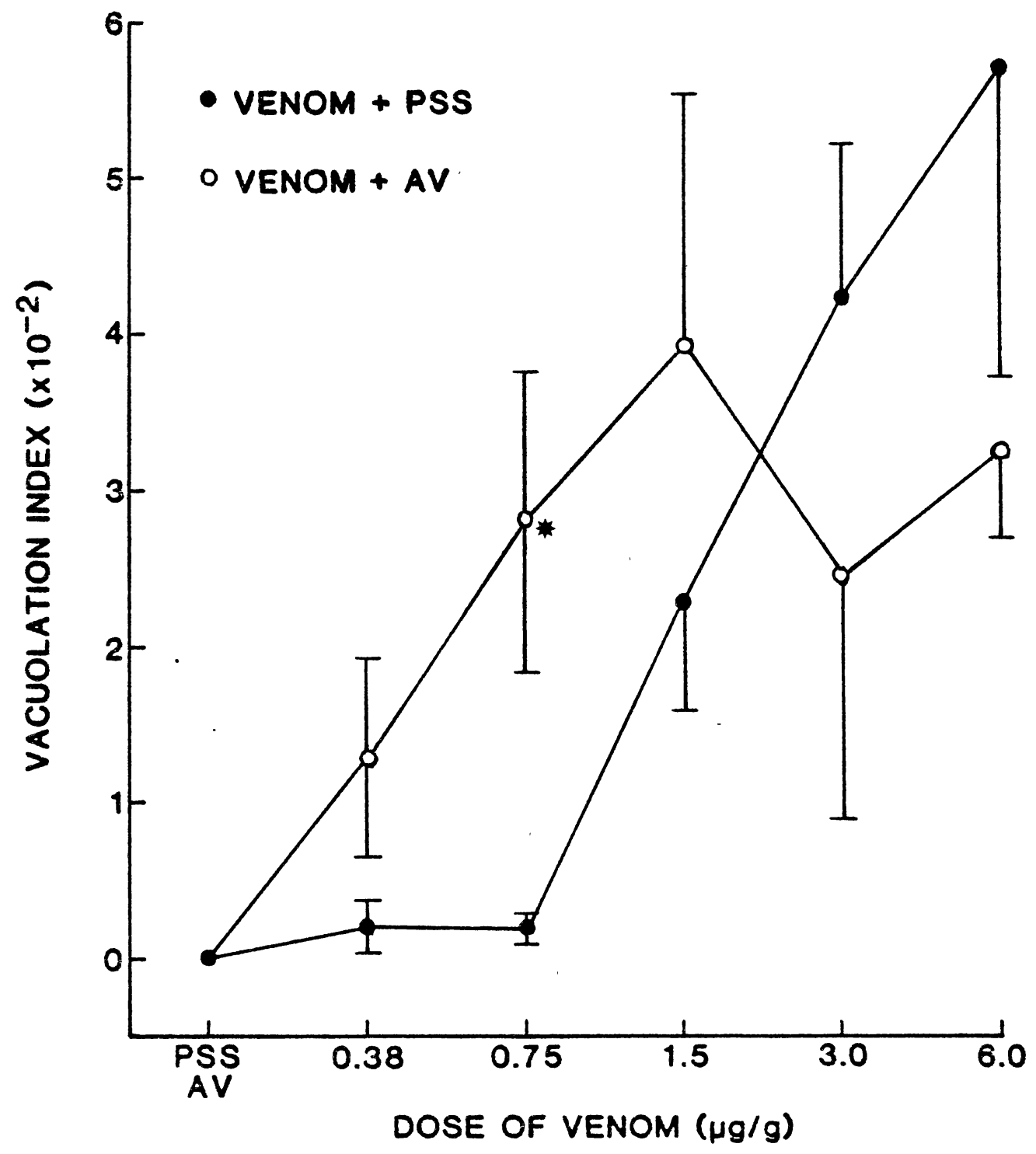


Figure 8. Effect of polyvalent antivenom on myonecrosis induced by crude crotalus
venom injected $i . m$. in female white $\frac{\text { hice as }}{\text { micridus }}$ measured by myonecrosis index excluding vacuolated cells.

(oc.h. horridus venom + antivenom)

( C. h. horridus venom + PSS)

Values are mean + S.E. $(n=6)$

* indicates sign $\bar{i} f i c a n t$ at $p<0.05$ 


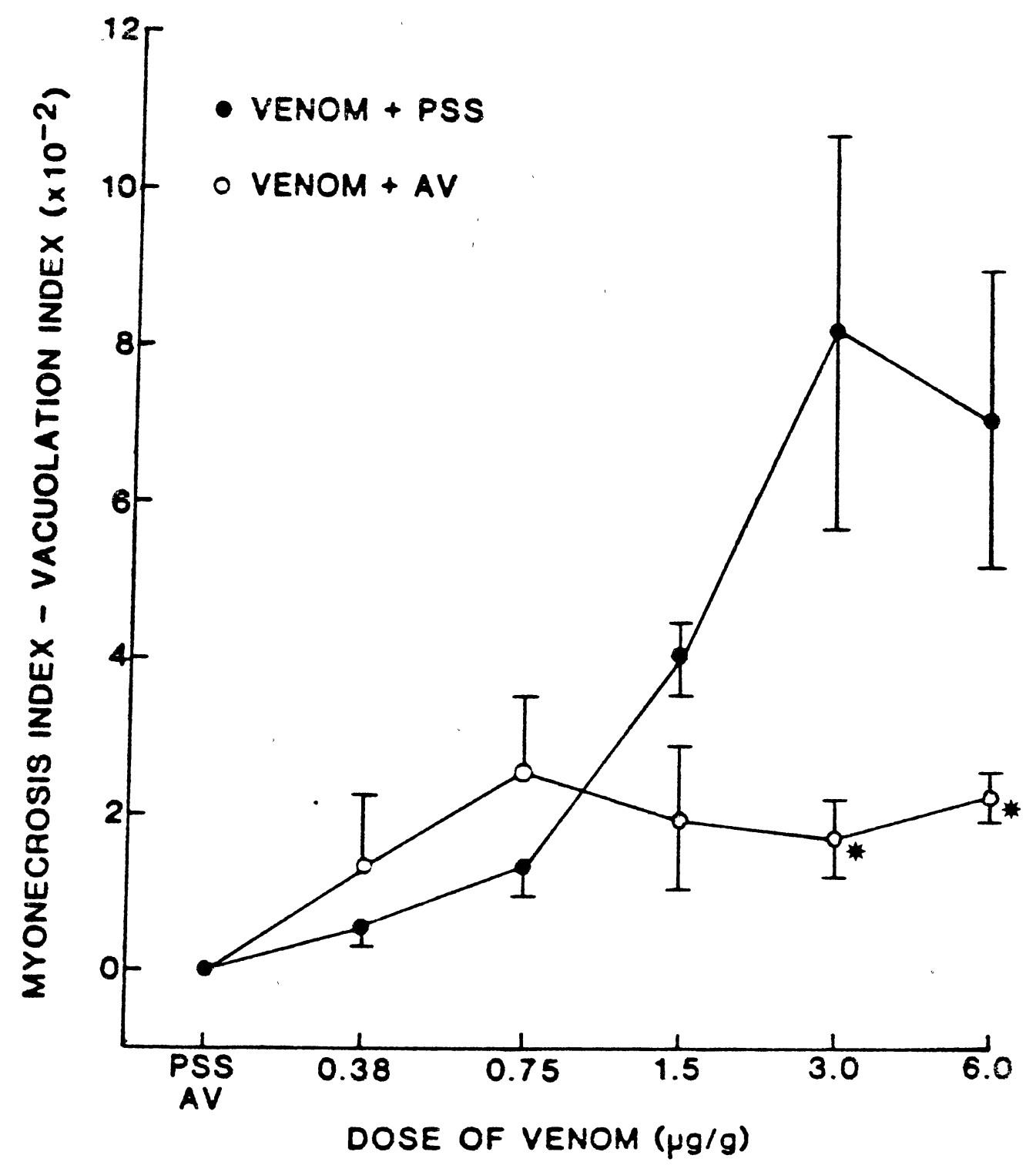


significantly reduce myonecrosis at doses of 3.0 and 6.0 micrograms/gram. There was a trend towards the reduction in necrosis at 1.5 micrograms/gram although not significant according to statistical analysis. There was also no significant reduction in myonecrosis at doses of 0.38 and $0.75 \mathrm{micrograms} / \mathrm{gram}$.

\section{Neutralization of Hemorrhage}

Figure 9 shows the ability of polyvalent antivenom to significantly neutralize $(p<0.05)$ the hemorrhagic activity of venom at doses between 3.0 and $12.0 \mathrm{micrograms} / \mathrm{gram}$. Although not significant, polyvalent antivenom markedly reduced hemorrhage at the $24.0 \mathrm{micrograms} / \mathrm{gram}$ dose. At doses of $1.5 \mathrm{micrograms} / \mathrm{gram}$ and lower, the amount of hemorrhage induced was too low for detection of a significant difference between the two treatments.

LD 50 Determination and Neutralization of Lethality

The LD 50 for $\underline{\text { C. }}$ h. horridus venom (10t \#9363) was determined to be $5.5 \mathrm{micrograms} / g r a m$. Neutralization studies showed that polyvalent antivenom was able to neutralize only a 2.5 times $L D_{50}$ dose of crude $\underline{c}$. $\underline{h}$. horridus venom. All mice 1 ived at 2.5 times the LD50 dose while all mice died when the same concentration of venom was mixed with $0.85 \% \mathrm{NaCl}$. All mice died at the 5.0 times LD 50 dose whether mixed with polyvalent antivenom or $0.85 \%$ $\mathrm{NaCl}$. 
Figure 9. Effect of polyvalent antivenom on the amount of hemorrhage induced by crude crotalus horridus horridus venom injected i.m. in female white mice as measured by mean corrected hemoglobin method.

(o c. h. horridus venom + antivenom) (- $\bar{c} \cdot \bar{h}$. horridus venom + PSS)

Values are meant S.E. $\quad(n=8$ unless otherwise indicated in parenthesis; all mice died in the venom + PSS 48.0 hour group)

* indicates significant at $p<0.05$ 


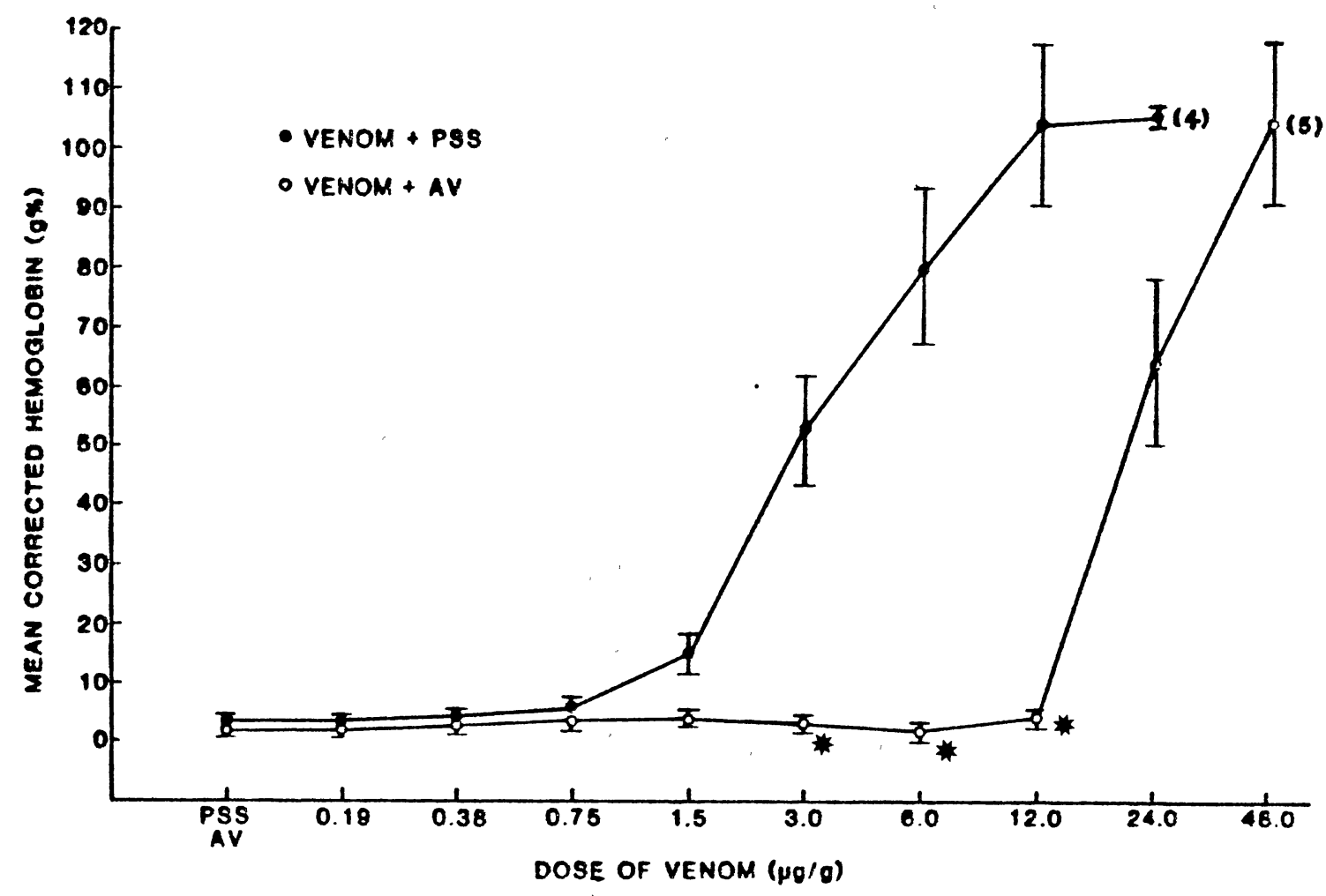




\section{Immunodiffusion}

Figure 10 shows the results of immunodiffusion plates. Two precipitin bands were formed between $\underline{c} \cdot \underline{h}$. horridus venom and polyvalent antivenom (undiluted) when the venom was placed in the center well at a concentration of $2 \mathrm{mg} / \mathrm{ml}$ (Figure 10A). Two precipitin bands also formed between undiluted polyvalent antivenom in the center well and $\underline{c}$. $\underline{h}$. horridus venom in the first three outer wells at concentrations of $2 \mathrm{mg} / \mathrm{ml}, 1 \mathrm{mg} / \mathrm{ml}$ and $0.5 \mathrm{mg} / \mathrm{ml}$ (Figure 10B). No bands were observed between polyvalent antivenom and $\underline{c}$. $\underline{h}$. horridus venom at lower concentrations of either solution. No bands were observed between venom and anti-myotoxin a serum using a venom concentration of 2 $\mathrm{mg} / \mathrm{ml}$.

\section{Summary}

Table I summarizes the ability of polyvalent antivenom to neutralize hemorrhage, myonecrosis and lethality, presented as the micrograms of venom neutralized by $0.1 \mathrm{ml}$ of polyvalent antivenom. The amount of venom neutralized when hemorrhage was measured very closely matches that neutralized when lethality was measured. 
Figure 10. Immunodiffusion plates containing polyvalent antivenom and crude crotalus horridus horridus venom. (A) Center well contains c. h. horridus venom at a concentration of 2. $0^{-} \mathrm{mg} / \mathrm{ml}^{\mathrm{T}}$. Outer wells contain serial two-fold dilutions of polyvalent antivenom beginning with undiluted antivenom in well one. (B) Center well contains undiluted polyvalent antivenom. Outer wells contain serial two-fold dilutions of $c$. $h$. horridus venom beginning with a concentration of 2.0 $\mathrm{mg} / \mathrm{ml}$ in well one. 

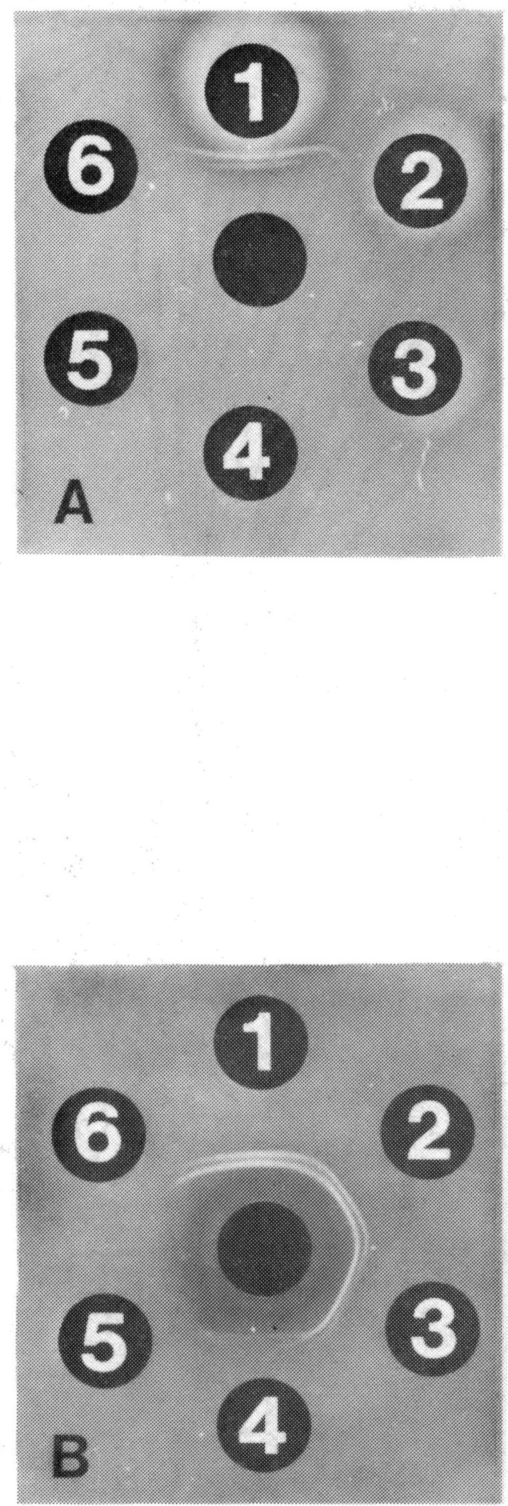


\section{TABLE I}

ABILITY OF POLYVALENT (CROTALIDAE) ANTIVENIN TO NEUTRALIZE Crotalus horridus horridus VENOM

Parameter

Measured

Venom Neutralized per

$0.1 \mathrm{ml}$ Antivenom

Myonecrosis

120 micrograms

Hemorrhage

240 micrograms

Lethality

210 micrograms

(performed in female white mice, i.m. injections) 


\section{CHAPTER IV}

\section{DISCUSSION}

The ability of polyvalent (Crotalidae) antivenin to neutralize the local effects (myonecrosis, vacuolation and hemorrhage) and lethality induced by $\underline{C}$. $\underline{h}$. horridus venom was investigated. Myonecrosis induced by $\underline{C}$. $\underline{h}$. horridus venom resembles that induced by $\underline{c}$. $\underline{v}$ viridis venom. The present study with $\underline{C}$. $\underline{h}$. horridus venom shows the apparent presence of a myotoxin a-like component, evidenced by the similarity in the vacuolation produced by $\underline{c}$. $\underline{\text { h. horridus }}$ venom to that produced by pure myotoxin a (see Figure 1 ). In 1977 , Cameron and Tu reported the isolation of a small (MW 4,100 daltons), basic polypeptide from the venom of $\underline{C}$. v. viridis. Ownby et al. (1976) illustrated the effects of this compound, myotoxin a, on skeletal muscle. Necrosis induced by myotoxin a was shown to be very similar to that

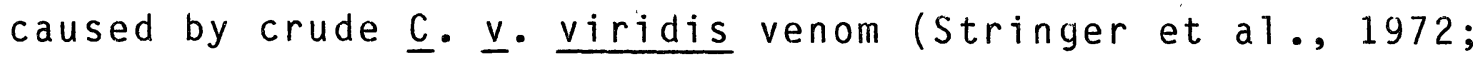
Ownby et al., 1983). The vacuolation that occurs with myotoxin a and the homologous crude venom results when the amount of extracellular fluid inside the cell increases, manifested by dilatation of the sarcoplasmic reticulum, producing vacuoles. Ownby et al. (1976) proposed that myotoxin a might inhibit the $\mathrm{Na}^{+} / \mathrm{K}^{+}$ATPase, allowing influx 
of $\mathrm{Na}^{+}$and water, resulting in vacuolation and eventually necrosis of skeletal muscle cells. Crotamine, another small molecular weight (5,000 daltons), basic protein isolated from the venom of $\underline{C}$. durissus terrificus and shown by Cameron and Tu (1978) to be almost identical to myotoxin $\underline{a}$, has been shown to cause an increase in the influx of ${ }^{24} \mathrm{Na}^{+}$across the sarcolemma (Chang and Tseng, 1978) by interacting with a sodium channel regulator.

The pathogenesis of myonecrosis induced by $\underline{c}$. $\underline{h}$. horridus venom (see Figure 3 ), however, indicates that vacuolation does not contribute a large part to the death of muscle cells. The number of cells that are vacuolated peaks at 12 hours after injection of a $4.0 \mathrm{micrograms} / \mathrm{gram}$ dose. Even at this point, vacuolated cells represent only $33 \%$ of the total necrotic cells. Although it became impossible to quantitate the necrosis induced by this dose after 48 hours due to the difficulty in distinguishing individual cells, the number of vacuolated cells appeared to decrease in number consistently after 12 hours. Myonecrosis, however, showed a steady increase over time, having not reached a peak even at 48 hours. The question remains as to whether all vacuolated cells ultimately become necrotic. The type of study presented here cannot address this question. One can state, however, that the contribution of vacuolated cells to the total necrosis induced by crude $\underline{c}$. $\underline{h}$. horridus venom is somewhat small compared to $\underline{c}$. $\underline{v}$ viridis venom although some contribution 
is obvious. Calculations from eight experiments performed by Ownby et al. (1983) show that at the doses of $0.38,0.75$

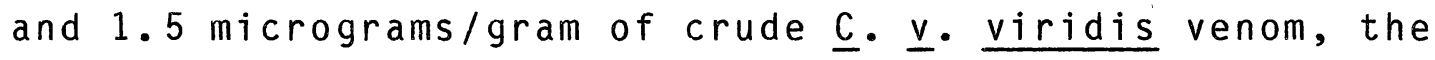
contribution of vacuolated cells to total myonecrosis are $61.1 \%, 33.1 \%$ and $49.8 \%$, respectively. The values for crude $\underline{\text { C. }} \underline{\text { h. horridus }}$ at the same doses are $26.7 \%, 11.9 \%$ and $36.2 \%$, based on data from six experiments.

The ability of polyvalent antivenom to neutralize myonecrosis induced by crude $\underline{c}$. $\underline{h}$. horridus venom is somewhat difficult to explain. The results showed significant neutralization at the 3.0 and 6.0 micrograms/gram doses of venom. Ownby et al., (1983) reported that polyvalent antivenom neutralized only a 0.38 micrograms/gram dose of crude $\underline{c}$. $\underline{v}$ viridis venom. The neutralization of myonecrosis induced by $\underline{c}$. $\underline{h}$. horridus venom may be due to antibodies present in the antivenom against myotoxic components of the venom. Additionally, however, some myonecrosis could be due to ischemia of the muscle cells as a result of hemorrhage caused by the venom. Therefore, neutralization of hemorrhage at these doses could indirectly lead to reduction of myonecrosis. Immunodiffusion shows the presence of antibodies in polyvalent antivenom to crude $\underline{c}$. $\underline{h}$. horridus venom, although it is impossible to say from this study whether these are directed against hemorrhagic toxins, myotoxins, or against viriditoxin-like components of the venom that cause both hemorrhage and myonecrosis (0wnby et a1., 1978; 
Fabiano and Tu, 1981; Gleason et al., 1983).

The failure of antivenom to neutralize myonecrosis at lower doses of venom is inconsistent with that observed at higher doses. At doses below $1.5 \mathrm{micrograms} / \mathrm{gram}$ of crude C. h. horridus venom, addition of polyvalent antivenom before injection appears to enhance necrosis of the muscle cells. This seems to be due to an increase in vacuolation. At a dose of $0.75 \mathrm{micrograms} / g r a m$, there is a significant $(p<0.05)$ increase in vacuolation with the addition of antivenom as compared to $0.85 \% \mathrm{NaCl}$ (see Figure 7 ). Analysis of variance for the data presented in Figure 7 indicated interaction between the treatment and dose at the 0.75 micrograms/gram dose. Comparing graphs presented in Figures 6 and 8 , one can see by excluding vacuolated cells from the total necrotic cells, the graphs more closely resemble each other at the lower doses. Working with crude ‥ ‥ viridis venom, Ownby et al. (1983) showed similar results with vacuolation when comparing venom plus $0.85 \%$ $\mathrm{NaCl}$ and venom plus normal horse serum, where vacuolation with horse serum was significantly $(p<0.05)$ higher than that with physiologic saline. This would indicate some interaction between the horse serum and the venom resulting in an increase in vacuolation. As polyvalent antivenom is horse serum, the two sets of data are consistent. Antivenom is, however, able to neutralize necrosis of muscle at higher doses and is more effective against $\underline{C}$. $\underline{h}$. horridus venom than $\underline{C}$. $\underline{v}$. viridis venom, perhaps due 
to the lesser importance of myotoxin $\underline{a}$ in $\underline{c}$. $\underline{h}$. horridus venom.

Polyvalent antivenom was able to significantly neutralize hemorrhage induced by doses of $3.0,6.0$ and 12.0 micrograms/gram of crude $\underline{c}$. $\underline{h}$. horridus venom and to markedly reduce hemorrhage at a $24.0 \mathrm{micrograms} / g r a m$ dose. Doses below 3.0 micrograms/gram did not cause enough hemorrhage to detect any significant difference between means of either treatment. This corresponds well with data presented by Ownby et al. (1984a) in which polyvalent antivenom significantly reduced $(p<0.05)$ hemorrhagic activity at a $24.0 \mathrm{micrograms} / \mathrm{gram}$ dose of $\underline{c}$. $\underline{v}$. viridis venom and a 12.0 micrograms/gram dose of $\underline{C}$. atrox venom. At the higher doses ( 12.0 and $24.0 \mathrm{micrograms} / \mathrm{gram})$ of $\underline{\mathrm{C}}$. h. horridus venom, the amount of hemorrhage seems to plateau. This could be because hemorrhage has reached its highest peak. However, it may also be due to a technical problem caused by a loss of blood while the tissue was being removed since the amount of blood present was great. At these higher doses, much of the blood is removed with the skin during tissue removal. The results do indicate that polyvalent antivenom is very effective in neutralizing hemorrhage induced by crude $\underline{c}$. $\underline{h}$. horridus venom, neutralizing slightly more than two times the reported LD 50 .

The lethal activity of crude $\underline{c}$. $\underline{h}$. horridus venom is most likely due to the interaction of several toxins in the 
venom (Sullivan et al., 1978). The presence of several toxic components has been reported, including a neurotoxin (Bonilla and Fiero, 1971), a phospholipase A (Kocholaty et a1., 1971), a bradykinin releasing enzyme (Deutsch and Diniz, 1955), and several hemorrhagic toxins (Sullivan et a1., 1979; Civello et a1., 1983a). Of these, the hemorrhagic toxins are probably most important in lethality since three of five hemorrhagic toxins isolated from $\underline{c}$. $\underline{\text { h }}$. horridus venom by Sullivan et al. (1979) proved to be lethal. In the present study, examination of dead animals injected i.m. with lethal doses showed large amounts of blood and fluid in the abdominal cavity. The LD 50 for the venom used in this study of $5.5 \mathrm{micrograms/gram} \mathrm{was}$ determined using an i.m. injection route. Moran and Geren (1979) reported an LD 50 of 5.1 micrograms/gram using a s.c. route for $\underline{c}$. $\underline{h}$. horridus venom. 0ur results show that antivenom can neutralize a 2.5 times LD 50 dose ( 5.5 micrograms/gram) but not a 5.0 times LD 50 dose. Much of this neutralization may be due to the effectiveness of antivenom to neutralize hemorrhagic activity. This is supported by the fact that all mice died in the $0.85 \% \mathrm{NaCl}$ control group receiving doses of $48.0 \mathrm{micrograms} / \mathrm{gram}$ while those receiving polyvalent antivenom all lived (see figure 9). Ownby et al. (1983) showed that polyvalent antivenom, when injected i.m., neutralized six times the LD 50 (3.0

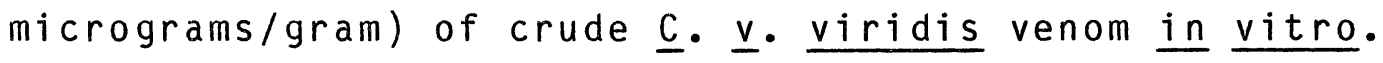


In conclusion, the present study indicates that the most widely used antivenom in the United States, polyvalent (Crotalidae) antivenin, is able to neutralize myonecrosis at doses of 3.0 and $6.0 \mathrm{micrograms} / \mathrm{gram}$, hemorrhage induced by doses of $3.0,6.0$ and $12.0 \mathrm{micrograms} / \mathrm{gram}$ and lethality induced by 2.5 times the LD 50 for crude $\underline{\text {. }} \underline{\text { h. horridus }}$ venom. 


\section{LITERATURE CITED}

Allam, M. W., Weiner, D. and Lukens, F. D. W. (1956) Comparison of cortisone and antivenin in the treatment of Crotaline envenomation. In: Venoms, pp. 393-397 (Buckley, E. E. and Porges, N., Eds.). Washington D.C., American Association for the Advancement of Science.

Bonilla, C. A. and Fiero, M. K. (1971) Comparative biochemistry and pharmacology of salivary gland secretions II. Chromatographic separation of the basic proteins from some North American rattlesnake venoms. J. Chromatog. 56: 253-263.

Cameron, D. L. and Tu, A. T. (1977) Characterization of myotoxin a from the prairie rattlesnake (Crotalus viridis viridis). Biochemistry 16: $2546-2553$.

Cameron, D. L. and Tu, A. T. (1978) Chemical and functional homology of myotoxin a from prairie rattlesnake venom and crotamine from South American rattlesnake venom. Biochemica et Biophysica Acta. 532: $147-154$.

Chang, C. C. and Tseng, K. H. (1978) Effect of crotamine, a toxin from South American rattlesnake venom, on the sodium channel of murine skeletal muscle. Br. Pharmac. 63: 551-559.

Civel1o, D. J., Duong, H. L. and Geren, C. R. (1983a) Isolation and characterization of a hemorrhagic proteinase from timber rattlesnake venom. Biochemistry 22: 749-755.

Civello, D. J., Moran, J. B. and Geren, C. R. (1983b) Substrate specificity of a hemorrhagic proteinase from timber rattlesnake venom. Biochemistry 22: 755-762.

Criley, B. R. (1956) Development of a multivalent antivenin for the family Crotalidae. In: Venoms, Washington D.C., American Association for the Advancement of Science.

Deutsch, H. F. and Diniz, C. R. (1955) Some proteolytic activities of snake venoms. ․ Biol. Chem. 216: $17-26$. 
Efrati, P. (1979) Symptomology, pathology and treatment of the bites of viperid snakes. In: Snake Venoms, pp. 956-977 (Lee, C. Y., Ed.). B erlin:

Springer-Verlag.

Fabiano, R. J. and Tu, A. T. (1981) Purification and biochemical study of viriditoxin, tissue damaging toxin, from prairie rattlesnake venom. Biochemistry 20: $21-27$.

Gleason, M. L., 0de11, G. V. and Ownby, C. L. (1983) Isolation and biological activity of viriditoxin and viriditoxin variant from Crotalus viridis viridis venom. J. Toxicol-Toxin Reviews $2(2): 23 \frac{15}{5-265 .}$

Glenn, J. L. and Straight, R. C. (1984) Effects of pressure-immobilization on the systemic and local action of venoms in a mouse tail model. Abstract presented at First American Symposium on Animal, Plant and Microbial Toxins, Stillwater, Oklahoma. Toxicon (in press).

Huang, T. T., Lynch, J. B., Larson, D. S. and Sevis, S. R. (1974) Management of snakebite. Ann Surg. 179: 598-607.

Iwanaga, S. and Suzuki, T. (1979) Enzymes in snake venoms. In: Venoms, pp. 61-158 (Lee, C. Y., Ed.). Berlin: Springer-Verlag.

Kocholaty, W. F., Ledford, E. B., Daly, J. F. and Billings, T. A. (1971) Toxicity and some enzymatic properties and activities in the venoms of Crotalidae, Elapidae, and Viperidae. Toxicon 9: 131-138.

Litchfield, J. T. and Wilcoxon, F. (1949) A simplified method of evaluating dose effect experiment. $\underline{J}$. Pharmac. Exp. Ther. 96: 99-113.

McCollough, N. C. and Gennaro, J.F. (1970) Treatment of venomous snakebite in the United States. Clinical Toxicology 3(3): $482-500$.

Minton, S. A. (1954) Polyvalent antivenin in the treatment of experimental snake venom poisoning. Am. J. Trop. Med. Hyg. 3: 1077-1082.

Minton, S. A. (1976) Neutralization of old world viper venoms by American pit viper antivenin. Toxicon 14: 146-148. 
Moran, J. B. and Geren, C. R. (1979) A comparison of biological and chemical properties of three North American (Crotalidae) snake venoms. Toxicon 17: $237-244$.

Ohsaka, A. (1979) Hemorrhagic, necrotizing and edema forming effects of snake venoms. In: Snake Venoms, pp.480-546 (Lee, C. Y., Ed.). Beriin: SpringerVerlag.

Ownby, C. L., Cameron, D. and Tu, A. T. (1976) Isolation of myotoxic component from rattlesnake (Crotalus viridis viridis) venom: electron microscopic analysis of muscle damage. Am. ‥ Pathol. 85(1): 149-166.

Ownby, C. L., Bjarnason, J. and Tu, A. T. (1978) Hemorrhagic toxin from rattlesnake (Crotalus atrox) venom: pathogenesis of hemorrhage induced by three purified toxins. Am. J. Pathol. 93(1): 201-218.

Ownby, C. L., Woods, W. M. and Ode11, G. V. Antiserum to myotoxin from prairie rattlesnake (Crotalus viridis viridis) venom. Toxicon 17: $373-380$.

Ownby, C. L. (1982) Pathology of rattlesnake envenomation. In: Rattlesnake Venoms, pp. 163-210 (Tu, A. T., Ed.). New York: Marcel Dekker, Inc.

Ownby, C. L., Odell, G. V., Woods, W. M. and Colberg, T. R. (1983) Ability of antiserum to myotoxin a from prairie rattlesnake (Crotalus viridis viridis) venom to neutralize local myotoxicity and Tethal effects of myotoxin a and homologous crude venom. Toxicon 21(1): 35-45.

Ownby, C. L., Colberg, T. R. and Ode11, G. V. (1984a) A new method for quantitating hemorrhage induced by rattlesnake venoms: ability of polyvalent antivenin to neutralize hemorrhagic activity. Toxicon 22(2): $227-234$.

Ownby, C. L., Colberg, T. R., Claypool, L. and Odell, G. V. (1984b) In vivo test of the ability of antiserum to myotoxin a from prairie rattlesnake (Crotalus viridis viridis) venom to neutralize local myonecrosis induced by myotoxin a and homologous crude venom. Toxicon $22(1)$ : $\quad 99-1 \overline{0}$.

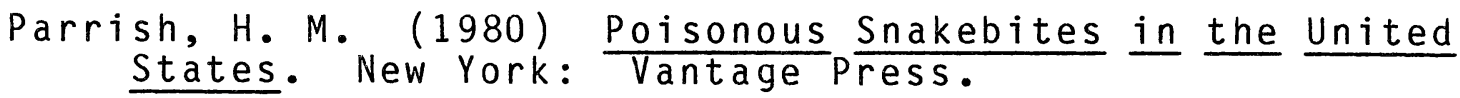


Russe11,F.E., Ruzic, N. and Gonzales, H. (1973) Effectiveness of antivenin (Crotalidae) polyvalent following injection of Crotalus venom. Toxicon 11: $461-464$.

Russe11, F. E., Wainschel, J., Carlson, R. W. and Osborne, A. (1975) Snake venom poisoning in the United States. JAMA 233(4): 341-344.

Schaeffer, R. C., Jr., Carlson, R. W., Puri, V.K., Callahan, G., Russell, F. E. and Weil, M H. (1978) The effects of colloidal and crystalline fluids on rattlesnake venom shock in the rat. . Pharm. Exp. Ther. 206: 687-695.

Schaeffer, R. C., Jr., Carlson, R. W. and Weil, M. H. (1979) The effects of antivenin and corticosteroid analogs on rattlesnake venom shock in the rat. Pharm. Exp. Ther. 211(2): 409-414.

Schottler, W. H. A. (1954) Antihistamine, ACTH, cortisone, hydrocortisone and anesthetics in snake bite. Am. J. Trop. Med. Hyg. 3: 1083-1091.

Stahnke, H. L., Allen, F.M., Horan, R. V. and Tenery, J.H. (1957) The treatment of snakebite. Am. . Trop. Med. Hyg. 6: $323-335$.

Stahnke, H. L. and McBride, A. (1966) Snake bite and cryotherapy. Journal of Occupational Medicine 8(2): $72-76$.

Stringer, J. M., Kainer, R. A. and Tu, A. T. (1972) Myonecrosis induced by rattlesnake venom: an electron microscopic study. Am J. Pathol. 67: 127-140.

Sullivan, J. and Geren, C. R. (1979) Isolation, stabilization and characterization of a toxin from timber rattlesnake venom. Prep. Biochem. 9(3): $321-333$.

Sullivan, J. A., Farr, E. and Geren, C. R. (1979) Fractionation and partial characterization of toxic components of timber rattlesnake venom. Toxicon 17: 269-277.

Sutherland, S. K. and Coulter, A. R. (1981) Early management of bites by the eastern diamondback rattlesnake (Crotalus adamanteus): studies in monkeys (Macaca fascicuTaris). Am. J. Trop. Med. Hyg. 30(2): $4 \overline{97-500}$. 
Swaroop, S. and Grab, B. (1956) The snakebite mortality problem in the world. Cited in: Ownby, C. L., Cameron, D. and Tu, A. T. (1976) Isolation of myotoxic component from rattlesnake (Crotalus viridis
viridis) venom: electron microscopic muscle damage. Am. ‥ Pathol. 85(1): 149-166.

Wilcox, R. E., Hightower, W. L. and Smith, R. V. (1979) Post-hoc data analysis in biomedical research. Am. Lab. 11: 32-45. 


\author{
VITA \\ Michael Scott Smith \\ Candidate for the Degree of \\ Master of Science
}

Thesis: ABILITY OF POLYVALENT (CROTALIDAE) ANTIVENIN TO NEUTRALIZE MYONECROSIS, HEMORRHAGE AND LETHALITY INDUCED BY TIMBER RATTLESNAKE (CROTALUS HORRIDUS HORRIDUS) VENOM

Major Field: Physiological Sciences

Biographical:

Personal Data: Born in Charlotte, North Carolina, August 11, 1957, the son of Christine M. Smith.

Education: Graduated from H. P. Harding High School, Charlotte, North Carolina, in June, 1975; received Bachelor of Science Degree in Biology from Guilford College in May, 1979; received North Carolina secondary teaching certificate from the University of North Carolina at Charlotte in May, 1981; completed requirements for the Master of Science degree at 0klahoma State University in July, 1984.

Professional Experience: High School Teacher, Forest Hills High School, Marshville, North Carolina, August, 1981 to June, 1982; Graduate Teaching Assistant, Department of Physiological Sciences, 0klahoma State University, August, 1982 to July, 1984 . 